\title{
Evaluation of index and compaction properties of lateritic soils treated with quarry dust based geopolymer cement for subgrade purpose
}

Kennedy Chibuzor ONYELOWE - Department of Civil Engineering,

Michael Okpara University of Agriculture, Nigeria • konyelowe@mouau.edu.ng

Duc BUI VAN - Research Group of Geotechnical Engineering, Construction Materials and Sustainability, Hanoi University of Mining and Geology, Vietnam

LAM DAO-PHUC - Research Group of Geotechnical Engineering, Construction Materials and Sustainability, Hanoi University of Mining and Geology, Vietnam

Favour ONYELOWE - Department of Biotechnology, Faculty of Science, Ebonyi State University, Nigeria Chidozie IKPA - Department of Civil Engineering, Faculty of Engineering,

Alex Ekwueme Federal University, Nigeria

CharLes EZUGWU - Department of Civil Engineering, Faculty of Engineering, Alex Ekwueme Federal University, Nigeria

A. Bunyamin SALAHUDEEN - Department of Civil Engineering, Faculty of Engineering, University of Jos, Nigeria

Michael MADUABUCHI - Department of Civil Engineering,

Michael Okpara University of Agriculture, Nigeria

JeSUBorN OBIMBA-WOGU - Department of Civil Engineering,

Michael Okpara University of Agriculture, Nigeria

Kızıтo IBE - Department of Civil Engineering, Michael Okpara University of Agriculture, Nigeria

LIGHT IHENNA - Department of Civil Engineering, Michael Okpara University of Agriculture, Nigeria

Érkezett: 2019. 11. 29. - Received: 29. 11. 2019. - https://doi.org/10.14382/epitoanyag-jsbcm.2020.2

\section{Abstract}

The effect of quarry dust based geopolymer cement on the index and compaction characteristics of soft problematic soils has been studied in the laboratory. The particular interest was on the geopolymer cement treatment of test problematic soils subgrade as hydraulically bound materials. In pavement foundation constructions, particular emphasis is always placed on how moisture suction and capillary actions affect the performance of the subgrade layer. Lateritic soils, which form the compacted foundation of pavements have the tendency to behave like plastics or liquids when in contact with moisture. These factors affect substantially the behavior and overtime performance, which is the durability of pavement subgrades. The primary aim of this research work was to adapt geopolymer cement synthesized from valorized solid waste materials (quarry dust and metallurgical slag). Laboratory experiments were used in this study. The test soils were observed to belong to A-2-6, A-2-7 and A-7 soils according to AASHTO classification, which are highly plastic and expansive. They are also of high clay content, a property which makes them unsuitable as moisture bound materials in foundations. The quarry dust based geopolymer cement was utilized at the rate of 10 to $150 \%$ by weight of dry soil in an increment of $10 \%$. The test soils treatment protocol shows that the additive consistently improved the plasticity index and maximum dry density of the treated soils obtained at optimum moisture condition. The results have shown that the environmentally friendly cement derived from the valorization of solid waste has improved the properties of the compacted earth utilized under moisture bound environment. So, it stands as a good replacement for ordinary cement.

Keywords: index properties, silicate-based materials, moisture bound composite materials, solid waste valorization, soil compaction, geopolymer cement, geotechnics

Kulcsszavak: szilikát alapú anyagok, szilárd hulladék felhasználása, talaj tömörítés, geopolimer cement, geotechnika

\section{Introduction}

Index properties of soils are the consistency behavioral patterns soils exhibit within the liquid and plastic phases when they are mixed with moisture. The liquid and plastic behaviors of soft cohesive fine-grained soils determine the soils abilities to be molded, rolled or compacted under different molding moisture conditions [1]. Liquidity of soils is very important
Kennedy Chibuzor ONYELOWE

is a senior lecturer and researcher at the department of civil engineering, Michael Okpara University of Agriculture, Umudike, Nigeria, an adjunct senior lecturer at the department of civi engineering, Alex Ekwueme Federal University,

Ndufu Alike Ikwo, Abakaliki, Nigeria and the principal investigator of the Research Group of Geotechnical Engineering, Construction Materials and Sustainability, Hanoi University of Mining and Geology, Hanoi, Vietnam. His research areas include soil stabilization, computational geotechnics, environmental geotechnics, structura construction materials, solid waste recycling wastes based geomaterials and geotechnical engineering.

Duc BUI VAN

is a lecturer at the Hanoi University of Mining and Geology, Hanoi, Vietnam and member of the research group of Geotechnical engineering, Construction Materials and sustainability, HUMG, Vietnam. His research area is geotechnica engineering.

Lam DAO-PHUC

is a professor of Geotechnical engineering at the HUMG and another important member of the research group of Geotechnical engineering, Construction Materials and sustainability, HUMG, Hanoi, Vietnam. He is also a published researcher in this field.

Favour ONYELOWE is an undergraduate student of the department of biotechnology, Ebonyi state university, Abakaliki, Nigeria. She is also a contributing author in the area of biomass and greenhouse emission sequestration during the combustion stage of ash derivation.

Chidozie IKPA

is currently a technologist in the department of civil engineering laboratory of the Alex Ekwueme University, Ndufu Alike lkwo, Nigeria. His research areas are construction materials, pavement materials, highway engineering and geotechnical engineering.

Charles N. EZUGWU is an Associate professor and the head of the department of civil engineering at the Alex Ekwueme Federal University Ndufu Alike lkwo, Nigeria. His research areas are water and environmental engineering, materials engineering waste recyclins

A. Bunyamin SALAHUDEEN is senior lecturer and researcher at the University of Jos, Nigeria. His research areas are geotechnical engineering, construction materials, soil mechanics, computational geotechnics, etc. He is a member of many professional and learned societies. in soil mechanics and foundation engineering as it determines certain design factors more especially when the materials are under hydraulically bound conditions [2]. Similarly, the compactibility of soils depend also on the molding moisture conditions or the consistency under which the compaction is carried out [3]. Compaction is a mechanical process of soil stabilization but the state of the soil being compacted plays a 
big role on the outcome of the compaction process [4]. For instance, highly plastic soils with plasticity index above $17 \%$, are difficult to handle compared to medium, less or nonplastic soils [5]. It is important to note that both properties of consistency and compaction are the responses of soils when mixed with moisture [6]. They both are moisture limits within which soils characteristics are determined [7]. In compaction, the maximum density of soils is achieved at a moisture intake mark called the optimum moisture [8]. The whole aim is to achieve densification of soil mass in a pavement foundation procedure [8]. But in this case, an ecofriendly supplementary cementitious compound has been developed to enhance the index and compaction properties of soft soils utilized as pavement underlain in the laboratory [1-4]. Researchers are working hard in this line to develop composite geomaterials that replace the conventional methods or materials, which bring about greenhouse emissions [9]. And one of such materials is the quarry dust based geopolymer cement, which was utilized to treat soils in varying proportions [10]. This cementitious compound is a combination of quarry dust, metallurgical slag and alkali activators [11]. Both quarry dust and metallurgical slag are industrial waste materials from quarry and metal operations. Quarry dust and metallurgical slag have been in use as stabilization silicate-based agents in the improvement of the mechanical properties of soils especially problematic soils for use as pavement subgrade materials [11]. This has been successful because of the high content of aluminosilicates possessed by these waste materials from quarry and metal operations. Their pozzolanic properties as single independent admixtures have been incorporated into the composite silicatebased cement compound synthesized under the reactive influence of alkali activators [11-13]. This work studied the effect of quarry dust based geopolymer cement on the index and compaction characteristics of treated problematic soils to be utilized as pavement foundation materials.

\section{Methodology}

\subsection{Materials preparation}

Three different borrow pit locations, with coordinates $5^{\circ} 29^{\prime} 16^{\prime \prime}$ North and $7^{\circ} 28^{\prime} 58^{\prime \prime}$ East (Olokoro location), 5 ${ }^{\circ} 27^{\prime} 0^{\prime \prime}$ North and 7 ${ }^{\circ} 31^{\prime} 60^{\prime \prime}$ East (Amaba location), and 5 $31^{\prime} 0^{\prime \prime}$ North and $7^{\circ} 26^{\prime} 0^{\prime \prime}$ East (Ohia location), were the source point of the test soils. Lumps were eliminated by tapping with rubber pestle, and open dried for four days to start of experiment procedure. Fundamental properties, particle size distribution and chemical compounds composition of the three studied soil specimens and test materials are presented in the Table 1, Fig. 1 and Table 2. The test soils have high free swell indexes and low shrinkage limits. This desiccation behavior makes the soils unsuitable as foundation materials. Exposure of these untreated test soils to moisture for a long time creates room for failures of infrastructures constructed on these soils because of the high potential to swell. It is also observed that the soils are highly plastic. This property also makes the untreated material unsuitable to be utilized as subgrade materials or as hydraulically bound materials. The A-2-7, A-2-6 and A-7 test soils are observed to be poorly graded soils [14]. Soils A and C contain high percentage of clay and are designated as highly clay $(\mathrm{CH})$ content soils, which is a property responsible for the expansivity of clayey soils in contact with moisture. Table 2 presents that the test materials have high percentage of aluminosilicate compounds. Quarry dust (QD) also contains high pozzolanic property [11]. The quarry dust based Geopolymer cement was synthesized according to the procedures and findings of Davidovits [12-13]. The aluminosilicate materials required to materialize the Geopolymer cements consist of quarry dust. The geopolymer cements synthesis was activated by the reactive stimulus of Sodium Hydroxide $(\mathrm{NaOH})$ and Sodium Silicate $\left(\mathrm{Na}_{2} \mathrm{SiO}_{3}\right)$ [12-13]. According to previous research findings, a molarity concentration $\mathrm{NaOH}$ of 12 was used to achieve an environmentally friendly material handling and construction process and better strength properties of geopolymer cement might be attained. The synthesis of geopolymer matrixes was carried out by mixing these above materials in a proportion of $4.8 \%$ activator, plus $80 \%$ quarry dust by weight and $15 \%$ metallurgical slag by weight [12-13].

\begin{tabular}{lccc} 
Property description of test soils & \multicolumn{3}{c}{ Values / Descriptions } \\
and units & Soil (A) & Soil (B) & Soil (C) \\
\% Passing Sieve, No $\mathbf{2 0 0}$ & 2.85 & 10 & 4.6 \\
\hline NMC (\%) & 12.1 & 13.49 & 14 \\
\hline LL (\%) & 40 & 46 & 64 \\
\hline PL (\%) & 18 & 21 & 36 \\
\hline PI (\%) & 22 & 25 & 28 \\
\hline SL (\%) & 8 & 8 & 7 \\
\hline FSI (\%) & 250 & 250 & 275 \\
\hline G & 2.6 & 2.43 & 2.12 \\
\hline AASHTO Classification & A-2-7 & A-2-6 & A-7 \\
\hline USCS & GP, CH & GP & GP, CH \\
\hline MDD (g/cm ${ }^{3}$ ) & 1.76 & 1.85 & 1.80 \\
\hline OMC (\%) & 13.1 & 16.2 & 13.13 \\
\hline CBR (\%) & 12 & 13 & 8 \\
\hline Color & Reddish & Reddish & Reddish \\
& Brown & Gray & Ash
\end{tabular}

Table 1 Basic properties of test soils 1. táblázat A vizsgált talajok alapvető tulajdonságai

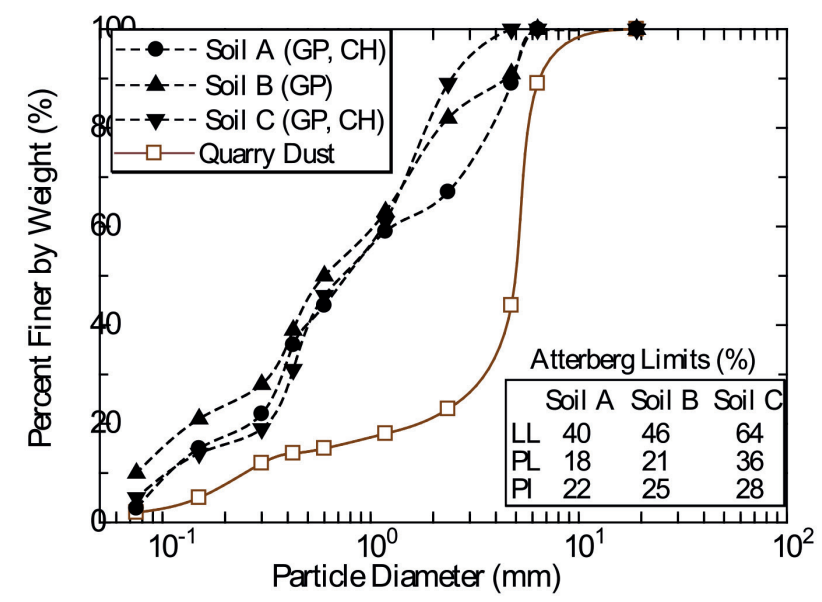

Fig. 1 Grain size distribution of studied materials

1. ábra A vizsgált anyagok szemmegoszlása 


\begin{tabular}{|c|c|c|c|c|c|c|c|c|c|c|c|c|c|}
\hline \multirow[t]{2}{*}{ Materials } & \multicolumn{13}{|c|}{ Oxides composition (content by wt \%) } \\
\hline & $\mathrm{SiO}_{2}$ & $\mathrm{Al}_{2} \mathrm{O}_{3}$ & $\mathrm{CaO}$ & $\mathrm{Fe}_{2} \mathrm{O}_{3}$ & MgO & $\mathrm{K}_{2} \mathrm{O}$ & $\mathrm{Na}_{2} \mathrm{O}$ & $\mathrm{TiO}_{2}$ & LOI & $\mathbf{P}_{2} \mathbf{O}_{5}$ & $\mathrm{SO}_{3}$ & IR & Free $\mathrm{CaO}$ \\
\hline Soil A & 76.56 & 15.09 & 2.30 & 2.66 & 0.89 & 2.10 & 0.33 & 0.07 & - & - & - & - & - \\
\hline Soil B & 77.57 & 14.99 & 3.11 & 1.78 & 0.86 & 1.45 & 0.23 & 0.01 & - & - & - & - & - \\
\hline Soil C & 77.73 & 16.65 & 1.42 & 3.22 & 0.07 & 0.89 & 0.02 & - & - & - & - & - & - \\
\hline QD & 63.48 & 17.72 & 5.56 & 1.77 & 4.65 & 2.76 & 0.01 & 3.17 & 0.88 & - & - & - & - \\
\hline
\end{tabular}

${ }^{*}$ IR is Insoluble Residue, LOI is Loss on Ignition, QD: Quarry Dust

Table 2 Chemical oxides compounds composition of the materials used in this paper 2. táblázat A viszgált anyagok kémiai összetétele

\subsection{Experimental methods}

Preliminary conventional tests; particle size distribution, Atterberg limits, compaction, free swell test and shrinkage limit tests, were conducted to determine the basic properties of the test soils in accordance with British standards [15-17].

Laboratory tests were conducted on the soils treated with varying proportions of quarry dust based geopolymer cement (QDbGPC) at the rate of $10 \%, 20 \%, 30 \%$ to $150 \%$ by weight of the dry soil to the determine the index properties of the treated soils in accordance with British Standards [16]. Similarly, the standard proctor compactive effort was used on test involving moisture/density relationship. Air dried soils samples passing through sieve number 4 (4.76 $\mathrm{mm}$ aperture BS sieve) mixed with $10 \%, 20 \%, 30 \%$ to $150 \%$ by weight of the dry soil of the ecofriendly binding admixture were used. The Standard Proctor procedure was conducted in the laboratory in accordance with British Standard [16].

\section{Results and analysis}

\subsection{Consistency limits and compaction behavior}

The consistency behavior of QDbGPC treated uncemented lateritic soils are presented in Fig. 2. The plasticity indexes (PI) of the natural untreated lateritic soils were recorded as 22, 25 and $28 \%$ respectively. These were considered highly plastic soils and undesirable as construction materials. Upon the treatment of these soils with QDbGPC, the PI was observed to reduce consistently at the rate of $18 \%, 8 \%$ and $4 \%$ respectively at $10 \%$ by weight utilization of the geopolymer cement. On further treatment with the geopolymer cement at $20 \%$ to $100 \%$ by weight utilization, the PI consistently reduced at the rate of $9 \%$ for treated soils A and B and 13\% for treated soil C. At $130 \%$, $140 \%$ and $150 \%$ utilization of the geopolymer cement, the consistency behavior of soil A showed a steady PI of $4 \%$. This observed behavior of the treated soils has been contributed by increased calcium content from the geopolymer cement blend to hydration reaction and calcination. This was also due to the rearrangement of molecules during the formation of transitional compounds. The hydration and calcination of the treated soils under high proportional aluminosilicate and pozzolanic geopolymer cement had caused this improvement. This however, produced stabilized treated soils of stiff consistency. Moreover, the cations release deposited at the adsorbed complex interface of the treated soils from the synthesized geopolymer cement constituents during the cation exchange reaction had also caused this reaction [18-19]. This proves that the mechanical factors of the treated soils would remain steady with the usual reduction in the liquid limits on addition of the treatment material if water is used as pore fluid. With the foregoing, under the addition of varying proportions of quarry dust based geopolymer cement, it can be deduced that the liquid limits and plasticity indexes depend on the mechanical conditions rather than the viscosity of pore fluid and density of the treated matrix [18-20]. But to a higher degree, this treatment protocol results is a function of carbonation, cation exchange, polymerization and polycondensation, which are physicochemical properties. Having achieved treated materials matrix of plasticity index below 15\%, the utilization of quarry dust based geopolymer cement has improved the treated lateritic soils such that they can best be used at nonfrost-susceptible subgrade and subbase materials. That is to say that under hydraulically bound or moisture bound conditions, the materials can adjust with great flexibility to withstand the effect of that exposure. However, the goal of achieving a durable pavement or foundation facility would have been successful. Similarly, the results of the compaction behavior of the treated lateritic soils are presented in Fig. 3. The maximum dry density (MDD) improved consistently from 1.76, 1.85 and $1.80 \mathrm{~g} / \mathrm{cm}^{3}$ respectively at $0 \%$ by weight utilization of quarry dust based geopolymer cement to $2.125,2.5$, and $1.95 \mathrm{~g} / \mathrm{cm}^{3}$ respectively at $150 \%$ by weight utilization of quarry dust based geopolymer cement. On the other hand, the optimum moisture reduced in a consistent trend also. Moisture was required to cause a dissociation of cations and anions from the geopolymer cement during hydration to supply more $\mathrm{Ca}^{2+}$ for the cation exchange reaction [11]. This cation exchange reaction caused the consistent reduction of moisture content, which led to the formation of flocs of the clay particles hence the densification of the treated soils.

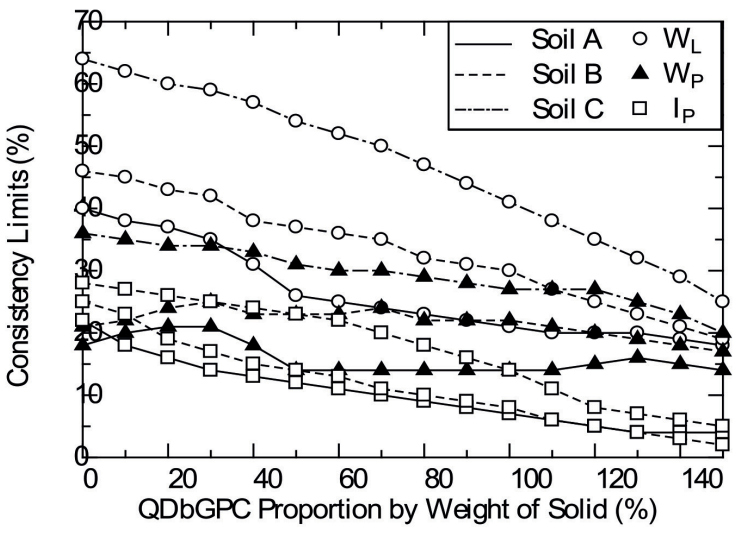

Fig. 2 Consistency limits of QDbGPC treated soils

2. ábra A QDbGPC-vel kezelt talajok tömörödési határétékei 


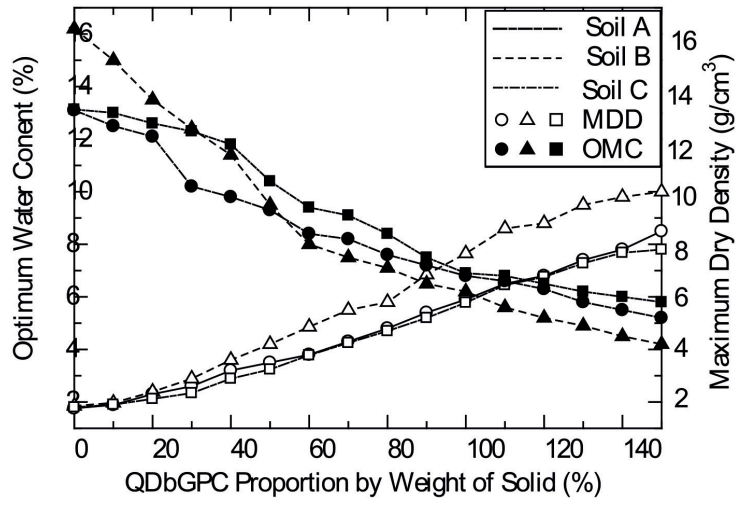

Fig. 3 Compaction behavior of QDbGPC treated soils

3. ábra A QDbGPC-vel kezelt talajok tömörödési viselkedése

\section{Conclusions}

The effect of solid waste based composite silicate based geopolymer cement, the quarry dust based geopolymer cement on the treated problematic soils has been observed under laboratory experiments. After the soils were treated through deep mixing with varying proportions of the composite ecofriendly cement, the index and compaction characteristics of the soils showed substantial and consistent improvement. The highly plastic soils improved to less plastic soils with plasticity indexes below $7 \%$ while the maximum dry densities obtainable at the optimum moisture condition also improved to good compactness. With the above observations, the quarry dust based composite geopolymer cement has proven to be a good supplementary cementing material for the stabilization of problematic soils and the improvement of the index and compaction properties when used as pavement subgrade materials exposed to moisture conditions.

\section{Acknowledgement}

The authors also would like to sincerely thank Vietnam Ministry of Education and Training for funding this research, Grant No. MOET /2019 with project number B2019-MDA-08.

\section{References}

[1] Onyelowe, K. C. - Bui Van, D.: Durability of nanostructured biomasses ash (NBA) stabilized expansive soils for pavement foundation, International Journal of Geotechnical Engineering, 2018. https://doi.org/10.1080/19386362.2017.1422909

[2] Onyelowe, K. C. - Bui Van, D.: Predicting Subgrade Stiffness of Nanostructured Palm Bunch Ash Stabilized Lateritic Soil for Transport Geotechnics Purposes. Journal of GeoEngineering of Taiwan Geotechnical Society, 2018. http://140.118.105.174/jge/index.php

[3] Onyelowe, K. C. - Bui Van, D.: Structural analysis of consolidation settlement behaviour of soil treated with alternative cementing materials for foundation purposes. Environmental Technology \& Innovation, Vol. 11, 2018, pp. 125-141. https://doi.org/10.1016/j.eti.2018.05.005

[4] Onyelowe, K. C. - Bui Van, D.: Predicting Strength Behaviour of Stabilized Lateritic Soil- Ash Matrix using Regression Model for Hydraulically Bound Materials Purposes, International Journal of Pavement Research and Technology, 2018. https://doi.org/10.1016/j.ijprt.2018.08.004

[5] Onyelowe, K. C. - Bui Van, D. - Eberemu, A. O. - Xuan, M. N. - Salahudeen, A. B. - Ezugwu, C. - Van, M. N. - Orji, F. - Sosa, F. - Duc, T. T. - Amhadi, T. - Ikpa, C. - Ugorji, B.: Sorptivity, swelling, shrinkage, compression and durability of quarry dust treated soft soils for moisture bound pavement geotechnics. Journal of Materials Research and Technology, 8(4), 2019:3529-3538. https://doi.org/10.1016/j.jmrt.2019.06.029

[6] Tan, Y. - Hu, M. - Li, D.: Effect of agglomerate size on California bearing ratio of lime treated lateritic soils. International Journal of Sustainable
Built Environment, Vol. 5 (1), 2016, Pp. 168-175.

https://doi.org/10.1016/j.ijsbe.2016.03.002

[7] Onyelowe, K. C. - Bui Van, Duc - Ubachukwu, Obiekwe - Ezugwu, Charles - Salahudeen, Bunyamin - Nguyen Van, Manh - Ikeagwuani, Chijioke Amhadi, Talal - Sosa, Felix - Wu, Wei - Ta Duc, Thinh - Eberemu, Adrian - Pham Duc, Tho - Barah, Obinna - Ikpa, Chidozie - Orji, Francis - Alaneme, George - Amanamba, Ezenwa - Ugwuanyi, Henry - Sai, Vishnu - Kadurumba, Chukwuma - Selvakumar, Subburaj - Ugorji, Benjamin: Recycling and Reuse of Solid Wastes; a Hub for Ecofriendly, Ecoefficient and Sustainable Soil, Concrete, Wastewater and Pavement Reengineering. International Journal of Low-Carbon Technologies. Vol. 14(3), 2019, pp. 440-451. https://doi.org/10.1093/Ijlct/Ctz028

[8] Onyelowe, K. C. - Salahudeen, A. B. - Eberemu, A. O. - Ezugwu, C. N. - Amhadi, T. - Alaneme, G.: Oxides of Carbon Entrapment for Environmental Friendly Geomaterials Ash Derivation. In book: Recent Thoughts in Geoenvironmental Engineering, Proceedings of the 3rd GeoMEast International Congress and Exhibition, Egypt 2019 on Sustainable Civil Infrastructures - The Official International Congress of the Soil-Structure Interaction Group in Egypt (SSIGE), 2020, pp. 58-67. https://doi.org/10.1007/978-3-030-34199-2_4

[9] K. C. Onyelowe, - A. B. Salahudeen, - A. O. Eberemu, - C. N. Ezugwu, - T. Amhadi,-G. Alaneme - F. Sosa: Utilization of Solid Waste Derivative Materials in Soft Soils Re-engineering. In book: Recent Thoughts in Geoenvironmental Engineering, Proceedings of the 3rd GeoMEast International Congress and Exhibition, Egypt 2019 on Sustainable Civil Infrastructures - The Official International Congress of the Soil-Structure Interaction Group in Egypt (SSIGE), 2020, pp. 49-57. https://doi.org/10.1007/978-3-030-34199-2_3

[10] Onyelowe, K. C. - Amhadi, T. - Ezugwu, C. N. - Onukwugha, E. Ugwuanyi, H. - Jideoffor, I. - Ikpa, C. - Iro, U. - Ugorji, B.: Cemented Lateritic Soil as Base Material Improvement Using Compression. In book: Innovative Infrastructure Solutions using Geosynthetics, Proceedings of the 3rd GeoMEast International Congress and Exhibition, Egypt 2019 on Sustainable Civil Infrastructures - The Official International Congress of the Soil-Structure Interaction Group in Egypt (SSIGE), 2020, pp. 58-67. https://doi.org/10.1007/978-3-030-34242-5_4

[11] American Standard for Testing and Materials (ASTM) C618. Specification for Pozzolanas. ASTM International, Philadelphia, 1978, USA.

[12] Davidovits, J.: Geopolymer Cement a review. Institute Geopolymer, F-02100, 2013, Saint-Quentin, France. [online]

[13] Abdel-Gawwadm, H. A. - Abo-El-Enein, S. A.: A Novel Method to Produce Dry Polymer Cement Powder. HBRC Journal. Vol. 12, 2016 Pp. 13-24. http://dx.doi.org/10.1016/j.hbrcj.2014.06.0018

[14] American Administration for State Highway Officials., AASHTO. Guide for Design of Pavement Structures, AASHTO, 1993, California, USA

[15] BS 1377 - 2, 3. Methods of Testing Soils for Civil Engineering Purposes, British Standard Institute, 1990, London.

[16] BS 1924. Methods of Tests for Stabilized Soil, British Standard Institute, 1990, London.

[17] Nigerian General Specification. Specification for Construction of Roads and Bridges, 1997, Nigeria.

[18] American Administration of State Highway and Transportation Officials, AASHTO T 22-03. Standard Method of Test for Compressive Strength of Cylindrical Concrete Specimens, 2014, Washington DC.

[19] American Administration of State Highway and Transportation Officials, AASHTO T 193-81. Standard Method of Test for The California Bearing Ratio of Compacted Soils, 2013, Washington DC.

[20] Hamidi, R. M. - Man, Z. - Azizli, K. A.: Concentration of $\mathrm{NaOH}$ and the Effect on the Properties of Fly Ash Based Geopolymer. $4^{\text {th }}$ International Conference of Process Engineering and Advanced Materials; Procedia Engineering, Vol. 148, 2016, Pp. 189-193. http://dx.doi.org/10.1016/j.proeng.2016.06.568

$\underline{\text { Ref.: }}$

Onyelowe, Kennedy Chibuzor - Bui Van, Duc - Dao-Phuc, Lam Onyelowe, Favour - Ikpa, Chidozie - Ezugwu, Charles Salahudeen, A. Bunyamin - Maduabuchi, Michael - ObimbaWogu, Jesuborn - Ibe, Kizito - Ihenna, Light: Evaluation of index and compaction properties of lateritic soils treated with quarry dust based geopolymer cement for subgrade purpose Építőanyag - Journal of Silicate Based and Composite Materials, Vol. 72, No. 1 (2020), 12-15. p. https://doi.org/10.14382/epitoanyag-jsbcm.2020.2 